\title{
THE EFFECT OF BODY CONDITION SCORE AND BODY WEIGHT OF SANJABI EWES ON IMMUNE SYSTEM, PRODUCTIVE AND REPRODUCTIVE PERFORMANCE
}

\author{
Mohammad Taher JALILIAN ${ }^{1,2}$, Mohammad Mahdi MOEINI ${ }^{3}$
}

Received April 18, 2013; accepted September 15, 2013.

Delo je prispelo 18. aprila 2013, sprejeto 15. septembra 2013.

\begin{abstract}
The effect of body condition score and body weight of Sanjabi ewes on immune system, productive and reproductive performance

Total 80 Sanjabi ewes ( $2-5$ years old and $50-85$ weight domain) were selected in animal unit of Mehregan farm. The ewes were divided to 4 treatment groups according to body condition score of $(2,2.5,3,3.5 \leq)$. Blood samples were collected from non-pregnant ewes, then after mating, two weeks before expected lambing and at lambing day. Blood samples of newborn lambs were also taken from the jugular vein at birth and 7 days of age. The reproductive parameters such as number of lambs born per lambing, $\mathrm{kg}$ of lambs born per ewes mating, pregnancy period and lamb birth weight were determined. Some blood metabolites such as glucose, total protein, albumin and globulin were determined. The white blood cell and differential leukocyte counts were also measured. The result of this experiment indicated that $\mathrm{BCS}=3$ had a significant effect $(\mathrm{P}<0.05)$ on the $\mathrm{kg}$ lambs born per ewes. Ewes with BCS $=3$ had a better performance in the percentage of lambs born per ewes at mating, while the lambing rate reduced in ewes with BCS of 3.5 or more. Birth weight of lambs was significantly affected by BCS of their ewes $(\mathrm{P}<0.05)$. There was a significant effect of BCS on plasma FSH concentration in ewes with BCS more than 3 but no significant difference was seen in blood metabolite in this study. Colostrum productions and the lamb birth weights were affected by body condition score of ewes. The white blood cell counts, neutrophils and lymphocytes counts did not change between ewes and lambs. It is concluded that BCS had a significant effect on $\mathrm{kg}$ lambs born per ewes, birth weight of lambs, lambs weaning weight and colostrum productions $(\mathrm{P}<0.05)$ and the score of 3 at mating time could optimize profitability of Sanjabi ewes.

Key words: sheep / breeds / Sanjabi / weight / body condition score / production / reproductive performance / immune system
\end{abstract}

Vpliv ocene kondicije in telesne mase na imunski sistem ter proizvodne in reprodukcijske lastnosti ovac pasme sanjabi

$\mathrm{V}$ poskus je bilo vključenih 80 sanjabi ovac s farme $\mathrm{Me}$ hregan v starosti 2-5 let. Ovce smo razdelili v štiri skupine glede na oceno telesne kondicije (BCS 2, 2,5, 3, 3,5 $\leq$ ). Vzorce krvi smo jemali od nebrejih ovac, takoj po paritvi, dva tedna pred pričakovano jagnitvijo in na dan jagnitve. Jancem smo jemali kri iz jugularne vene ob rojstvu in ko so bili stari 7 dni. Spremljali smo reprodukcijske parametre, kot so število jagnet na jagnitev, kg rojenih jagnet na paritev, dolžina brejosti in masa jagnet ob rojstvu. Določali smo nekatere parametre v krvi, kot npr. glukoza, skupne beljakovine, albumin in globulin. Prav tako smo spremljali število belih krvničk in diferencialno število levkocitov. Rezultati tega poskusa kažejo, da je ocena telesne kondicije ( $\mathrm{BCS}=3$ ) značilno vplivala na $\mathrm{k}$ rojenih jagnet na ovco. Ovce z BCS = 3 so imele višji odstotek jagnet rojenih na paritev, medtem ko je bil delež jagnitev zmanjšan pri ovcah $\mathrm{z}$ BCS 3,5 ali več. BCS je statistično značilno vplival na maso jagnet ob rojstvu $(\mathrm{p}<0,05)$. Prav tako je bil značilen vpliv BCS na koncentracijo FSH v plazmi pri ovcah z BCS višjim od 3, nismo ap zaznali razlik v koncentraciji metabolitov v krvi. BCS je vplival na proizvodnjo kolostruma in na maso jagnet ob rojstvu. Število belih krvničk, nevtrofilcev in limfocitov se med ovcami in jagneti ni razlikovalo. Ugotavljamo, da ima BCS značilen vpliv na kg rojenih jagnet na ovco, rojstno maso jagnet, maso jagnet ob odstavitvi in proizvodnjo kolostruma $(\mathrm{p}<0,05)$. BCS $3 \mathrm{v}$ času pripusta je optimalen za gospodarnost reje ovac pasme sanjabi.

Ključne besede: ovce / pasme / Sanjabi / teža / telesna kondicija / proizvodne lastnosti / reprodukcija / imunski sistem

1 Islamic Azad Univ., Dept. of Animal Sciences, Saveh Branch, Saveh, Iran

2 Corresponding author, e-mail: mtaherjalilian@gmail.com

3 Univ. of Razi, Dept. of Animal Sciences, Kermanshah, Iran 


\section{INTRODUCTION}

Small ruminant production is a very significant component of livestock production throughout the world and more especially in the developing countries (Ketema, T.K., 2007; Thornton et al., 2009). They were originally domesticated in southwest Asia, and Iran where today is the homeland of one of the first types of wild sheep (Dubeuf and Boyazoglu, 2009).

Body condition scoring has been widely adopted for managing the nutrition of flocks, especially when grazing, and for selecting lambs for purchase and slaughter. In Britain, and now increasingly in Europe, body scoring is based on a subjective assessment of the fat level and muscle thickness on the backbone behind the last rib (Treacher et al., 2000).

The relationship between BCS at calving and BCS loss was used to study the effect of conditioning of cows at calving and the subsequent severity of negative energy balance (EB) (Dechow et al., 2001). Body condition loss, as an indicator of EB, was used to study the impact of negative EB on stress symptoms, by correlating it to yield (Dechow et al., 2001), days to first insemination, services per conception, conception rate, conception rate after first insemination (Loeffler et al., 1999; Stevenson et al., 1999; Butler, 2001; Gillund et al., 2001) and oocyte development (Snijders et al., 2000).

In cattle and sheep, dietary energy restriction suppresses episodic release of LH (Schillo, 1992). Also data on the effects of nutritional stimuli on follicle stimulating hormone (FSH) levels during the cycle are equivocal, with reports for (Rhind et al., 1985, Rhind \& McNeilly, 1986) and against (Findlay and Cumming, 1976; Rhind et al., 1989; Xu et al., 1989; Smith and Stewart, 1990) the induction of a change. When they used ultrasonography to study the static effect of nutrition on daily follicular development, they found that the increased ovulation rate in ewes with high body condition was associated with increased FSH and decreased oestradiol concentrations during the follicular phase (Vinoles et al., 2002).

Gamez et al. (2008) demonstrated that BCS of goat passivity affected serum leptin concentration in a direct and proportional way, the better the BCS the greater serum leptin concentration during seasonal period. Zhang et al. (2005) showed that serum leptin concentration was positively correlated to BCS of sheep. Positive relationship have been shown between BCS and plasma leptin and FSH concentrations in Iranian fat tail ewes at mating time ( Towhidi et al., 2007). Vinoles et al. (2005) indicated that Lower oestradiol production by the follicles is most probably associated with the higher leptin levels inhibiting steroidogenesis in ewes in high body condition. The lower oestradiol concentrations reduce nega- tive feedback at the hypothalamus and pituitary gland, leading to higher circulating FSH concentrations.

Vinoles et al. (2005) found that ewes in high body condition score had a high ovulation rate, which is accompanied by high FSH and low oestradiol concentrations during the follicular phase, compared with ewes in low body condition. The pool of follicles available for the action of glucose and metabolic hormones may play a key role in stimulating an increase in ovulation rate. Ewes in high body condition had a higher number of gonadotrophin dependent follicles than did ewes in low body condition (Rhind and McNeilly, 1986, Rhind et al., 1989, Xu et al., 1989, Vinoles et al., 2005).

Ewes with very high level of body condition score show an increase in ova wastage and reduce in reproductive performance (Rhind et al., 1985). Low body condition was related with prevention of estrus and fertility (Rhind et al., 1985). Caldeira et al. (2007) reported on a variation in blood metabolic status at the different BCS. The metabolites could potentially be useful as indicators for predicting nutritional status. Blood metabolic profiles included different tests in accordance with each specific purpose have been proposed (Lee et al., 1978; Kida, 2002) including the Compton Metabolic Profile Test (Rowlands, 1980; Payne and Payne, 1987).

Using metabolic profiles on farms has not been adopted extensively, as it is thought that blood parameters cannot predict the metabolic status of an animal without a characterization of its diet and level of production (Rowlands, 1980). The information gained from some strategic metabolic indicators and BCS can, however, possibly provide a more substantial basis regarding the knowledge of the metabolic status of the ewes and therefore, diets can be adjusted and metabolic disorders prevented together with improved production.

Branca and Casu (1989) showed that the animals experience nutritional imbalances can result in a marked decrease in milk yield, low milk fat and protein content and abrupt changes of body condition score. Wildman et al. (2010) reported that dairy cows of greatest efficiency of milk production showed no significant increase in body condition during lactation, had fewer days open, but had lower persistency of lactation. Dairy cows that increased significantly in body condition during lactation were less efficient producers, had a greater number of days open, and had high body condition scores at the end of lactation.

The selected reproduction criteria: fertility (percentage of kidding goats), prolificacy or litter size and fertilization date (deducted from kidding date) were affected by different BCS (Jalilian et al., 2012). In addition, Jalilian et al. (2012) indicated that BCS had a significant effect on the kids born per goat at mating. In that study 
Table 1: Components, ingredients and nutrient composition of diets Preglednica 1: Sestava in hranilna vrednost obrokov

\begin{tabular}{|c|c|c|c|c|c|c|c|}
\hline Ingredient & alfalfa & wheat & corn & soybean meal & barley & wheat bran & total \\
\hline DM Feed (\%) & 55 & 15.3 & 12.6 & 8.1 & 5.4 & 3.6 & 100 \\
\hline $\mathrm{ME}(\mathrm{Mcal} / \mathrm{Kg})$ & 0.995 & 0.469 & 0.190 & 0.24 & 0.15 & 0.091 & 2.13 \\
\hline $\mathrm{CP}(\% \mathrm{DM})$ & 7.7 & 1.72 & 1.134 & 4.04 & 0.756 & 0.615 & 15.9 \\
\hline NDF (\% DM) & 31.9 & 1.48 & 3.52 & 1.20 & 1.51 & 1.83 & 41.44 \\
\hline ASH (\% DM) & 3.85 & 0.306 & 0.239 & 0.58 & 0.216 & 0.248 & 5.43 \\
\hline $\mathrm{Se}(\mathrm{mg} / \mathrm{kg})$ & 0.03 & 0.007 & 0.008 & 0.041 & 0.009 & 0.015 & 0.11 \\
\hline $\mathrm{Cu}(\mathrm{mg} / \mathrm{kg})$ & 7.535 & 1.193 & 1.00 & 1.81 & 0.46 & 0.50 & 12.49 \\
\hline $\mathrm{Zn}(\mathrm{mg} / \mathrm{kg})$ & 12.155 & 4.59 & 1.75 & 4.61 & 2.39 & 4.60 & 30.09 \\
\hline $\mathrm{Fe}(\mathrm{mg} / \mathrm{kg})$ & 93.5 & 6.12 & 11.42 & 14.98 & 4.86 & 4.60 & 135.48 \\
\hline
\end{tabular}

goats with BCS 3 had more normal estrous, while goats with low BCS had shorter estrous period.

The present study was designed to investigate the effect of different BCS on blood metabolites, reproduction and production performance of Sanjabi ewes.

\section{MATERIALS AND METHODS}

This experiment was conducted in Mehregan farm located in Kermanshah province in the west of Iran. Total 80 Sanjabi ewes ( $2-5$ years old and $50-85$ weight domain) were selected in animal unit of Mehregan farm. The ewes were fed alfalfa hay and concentrate (corn, soybean meal, barley, wheat bran) according NRC 1985 (Table 1). The ewes were homogeneous for time of lambing and oestrus was synchronized with two intramuscular injections of prostaglandin given 9 days apart.

Estrous behavior was detected by testing the ewes every $12 \mathrm{~h}$ with vasectomized rams from the day of the second PG injection and from day 15 of the next estrous cycle. A week before the mating time ewes were weighed and scored according their body condition score (BCS). Classification of BCS considered the dorsal palpation technique using the technique of Santucci and Maestrini
(1985). The BCS measurement based on height, weight and age in addition to an interval rang of 0.5 point. Ewes were divided to 4 treatment groups according to the BCS $(2,2.5,3,3.5 \leq)$ (Table2). The body condition score (BCS) was determined by the joint agreement of four judges. Blood samples were taken a few days before mating. Also blood samples were collected from ewes three weeks before expected lambing and at lambing day. Immediately after parturition, newborn lambs were taken away from ewes.

Blood sample of lambs were drown from the jugular vein at birth and 7 days of age. The lambs were housed in individual pens. For the first 48 hours of life, at 8-10 hour intervals, lambs of all groups were fed colostrum from their respective dams. Blood metabolic parameters (glucose, albumin and total protein) were determined by spectrophotometer using commercial kit (PERKINELMER35-Pars Azmon). Serum globulin concentrations were determined using the difference between serum total protein and albumin concentrations.

Blood samples were taken by heparinized venipuncture on day1 (when ewes showed estrus sign) and at mating time (day2). Blood tubes were centrifuged $(15 \mathrm{~min}$ at $4{ }^{\circ} \mathrm{C}$ and $3000 \times \mathrm{g}$ ) and plasma sample stored at $-20^{\circ} \mathrm{C}$ until FSH assay. FSH was measured by ELISA (Enzyme

Table 2: Body condition score, body weight and FSH concentration in Sanjabi ewes

Preglednica 2: Ocena telesne kondicije, masa telesa in koncentracija FSH pri ovcah pasme sanjabi

\begin{tabular}{|c|c|c|c|c|}
\hline \multirow[b]{2}{*}{ BCS } & \multirow{2}{*}{$\begin{array}{l}\text { Ewes body weight at } \\
\text { mating }(\mathrm{kg})\end{array}$} & \multirow{2}{*}{$\begin{array}{l}\text { Ewes body weight } \\
\text { after kidding (kg) }\end{array}$} & \multicolumn{2}{|l|}{ FSH (ng/ml) } \\
\hline & & & Day 1 & Day 2 \\
\hline 2.00 & $59.8 \pm 6.9$ & $60.5 \pm 5.8$ & $1.18 \pm 0.09$ & $2.50 \pm 0.13^{b}$ \\
\hline 2.50 & $66.7 \pm 8.8$ & $67.2 \pm 5.5$ & $1.19 \pm 0.11$ & $2.65 \pm 0.18^{a b}$ \\
\hline 3.00 & $73.9 \pm 7.3$ & $74.5 \pm 6.1$ & $1.25 \pm 0.10$ & $2.90 \pm 0.16^{\mathrm{a}}$ \\
\hline$\geq 3.5$ & $81.7 \pm 8.5$ & $83.4 \pm 6.8$ & $1.20 \pm 0.08$ & $2.89 \pm 0.13^{a}$ \\
\hline
\end{tabular}

$(\mu \pm \mathrm{SE})$ Mean \pm standard error; Means with different superscripts in the same row differ at $\mathrm{P}<0.05$ 
Table 3: Effect of body condition score on reproduction parameters Preglednica 3: Vpliv telesne kondicije na reprodukcijske parametre

\begin{tabular}{lcccc}
\hline Parameters & BCS 2 & BCS2.5 & BSC 3 & BSC $\geq 3.5$ \\
\hline Gestation length (days) & $159 \pm 3.45$ & $160 \pm 4.92$ & $158 \pm 3.34$ & $157 \pm 2.44$ \\
Lambs born / mated ewes (\%) & $133 \pm 35^{\mathrm{b}}$ & $155 \pm 40^{\mathrm{ab}}$ & $177 \pm 45^{\mathrm{a}}$ & $130 \pm 30^{\mathrm{b}}$ \\
Lamb birth weight (kg) & $3.9 \pm 0.4^{\mathrm{b}}$ & $5.3 \pm 0.21^{\mathrm{a}}$ & $5.55 \pm 0.3^{\mathrm{a}}$ & $4.18 \pm 0.5^{\mathrm{b}}$ \\
Lamb weaning weight (kg) & $20.9 \pm 3.4^{\mathrm{b}}$ & $20.3 \pm 3.21^{\mathrm{b}}$ & $24.21 \pm 3.3^{\mathrm{a}}$ & $23 \pm 3.5^{\mathrm{a}}$ \\
\hline
\end{tabular}

$(\mu \pm \mathrm{SE})$ Mean \pm standard error; Means with different superscripts in the same row differ at $\mathrm{P}<0.05$

linked Immune Sorbans Assay) using a commercial kit (DRG diagnostics, EIA-1561, DRG instrument GmbH, Germany/2003).

Body condition score (BCS) as experimental treatment parity was considered as a block and weight was considered as a covariate. From birth to 4 weeks of age, the lambs were housed in individual pens. For the first $36 \mathrm{~h}$ of life, lambs of all groups were fed colostrum from their respective ewes. Colostrum production of ewes was recorded during the first $18 \mathrm{~h}$ lactation. White blood cells (WBC) counts were performed using the manual standard method (Dacie and Lewis, 1984). Differential leukocyte counts were performed on routinely prepared Giemsa-stained blood films using the cross-sectional technique (Jain, 1986).

The experimental design was randomized complete block with twenty replication and four treatments. Ewes were blocked by body condition score (BCS). Plasma samples were analyzed by use of a repeated measure procedure using GLM procedure (SAS Version 9.1, SAS Inst. Inc., Cary, NC SAS, 2003). The relationships between reproductive variables were determined and statistical model was:

$\mathrm{Y}_{\mathrm{ijkmn}}=\mathrm{M}+\mathrm{A}_{\mathrm{i}}+\mathrm{B}_{\mathrm{j}}+\mathrm{E}_{\mathrm{k}}+\mathrm{S}_{\mathrm{m}}+\mathrm{D}_{\mathrm{n}}\left(\mathrm{S}_{\mathrm{m}}\right)+\mathrm{E}_{\mathrm{ij} \mathrm{kmn}}$

where $\mathrm{M}$ is the overall mean, $\mathrm{A}=\mathrm{BCS}$ of ewes, $\mathrm{E}=$ Age of ewes B = Body weight, $\mathrm{S}=$ Ram effect $\mathrm{D}(\mathrm{S})=$ Ewes effect/ Ram effect and Eijkmn the experimental random error.

\section{RESULTS AND DISCUSSION}

The reproductive parameters are shown in Table 3. The result of this study showed that the kilograms kids born in mated ewes with body condition score of 2.5 and 3 significantly were more than other groups. In addition, the lamb birth weights were affected by the treatments. The lamb birth weight was higher in body condition score of 3 compared with other groups (Table 3 ).

The average gestation lengths do not differ among all experimental groups. However the pregnancy lengths are reduced by increasing body condition score $(\mathrm{P}>0.05)$. Similarly, Jalilian et al. (2012) showed that the kilograms lamb born in mated Sanjabi ewes with body condition score of 3 were significantly more than in other groups. In the mentioned study the Sanjabi ewes with body condition score of 3 had a better performance in lambing rate and $\mathrm{kg}$ lambs born per ewes, while the lambing rate decreased in ewes with BCS 3.5 or more.

Rhind et al. (1985) reported that in ewes with high BCS (more than 4) the primary embryo wastage increased and reproductive performance decreased. Also

Table 4: Effect of Body condition score on blood metabolites in Sanjabi ewes

Preglednica 4: Vpliv telesne kondicije na metabolite v krvi pri ovcah pasme sanjabi

\begin{tabular}{|c|c|c|c|c|}
\hline Parameters (mg/dL) & BCS 2 & BCS 2.5 & BSC 3 & $\mathrm{BSC} \geq 3.5$ \\
\hline Glucose & $51 \pm 5.3$ & $53 \pm 5$ & $59 \pm 6.1$ & $55 \pm 5.9$ \\
\hline Total protein & $4.7 \pm 0.8$ & $4.5 \pm 0.7$ & $5.5 \pm 0.9$ & $4.9 \pm 0.8$ \\
\hline Insulin(ng/ml) & $1.21 \pm 0.08$ & $1.17 \pm 0.06$ & $1.15 \pm 0.07$ & $1.20 \pm 0.05$ \\
\hline Albumin & $3.81 \pm 0.4$ & $3.53 \pm 0.6$ & $4.00 \pm 0.6$ & $3.29 \pm 0.5$ \\
\hline Globulin & $1.17 \pm 0.11$ & $1.15 \pm 0.12$ & $1.26 \pm .14$ & $1.1 \pm 0.10$ \\
\hline HDL & $65.3 \pm 8.2$ & $67.7 \pm 6.1$ & $71.1 \pm 8$ & $66.3 \pm 6.6$ \\
\hline LDL & $25.5 \pm 6.3$ & $21.0 \pm 6$ & $20.3 \pm 6.1$ & $23.5 \pm 5.9$ \\
\hline Total Cholesterol & $99.2 \pm 8.7$ & $96.1 \pm 6.9$ & $93.6 \pm 9.5$ & $97.9 \pm 7.7$ \\
\hline
\end{tabular}

$(\mu \pm$ SE) Mean \pm standard error 
Vargas et al. (1999) suggested that body condition score had an impact on fertility rates in beef cattle. Rhind et al. (1985) showed that the body condition score more than 3 at mating caused low lamb production. The number of born lambs per ewe at mating was the highest in ewes with BCS of 2.75 , which reduced this trait by increasing the body condition score in amount of $37 \%$ (Rhind et al., 1985). The results of this study were in accordance to those achieved in the present study.

The body condition score did not affect the lambs' weight at birth but increased numerically from 2 to 3 (Aliyari et al., 2011). Jalilian et al. (2012) reported that the body condition score did not affect the kids' weight at birth. Body condition score had a significant effect on kilograms lambs born in ewes with BCS of 3 had a better reproductive performance.

The result of blood metabolites are indicated in Table 4 . The blood glucose, total protein, albumin, globulin concentrations and some other blood metabolites such as insulin, HDL, LDL and total cholesterol did not differ among the groups. Thomas et al. (1987) reported that body condition score at the end of pregnancy significantly improved the blood, glucose, globulin and total protein concentrations but not blood albumin. The responses of plasma insulin and glucose to dietary protein were consistent with the results of Van de Ligt et al. (2002) who indicated that equal amounts of amino acids were used by peripheral tissue, and excellent glucogenic regulation was executed by pigs in a fasting state. This ability for glucogenic regulation ability may be similarly possessed by ruminants. Insulin action, glucose and cholesterol metabolism, and lipogenesis in both liver and adipose tissue correlated with dietary protein levels (Santos et al., 2001; Sun et al., 2007).

The mean of plasma FSH concentrations did not differ in experimental groups at day one. On the other hand, the mean of plasma FSH concentrations in the ewes with BCS of 3 and 3.5 were significantly higher than in other experimental groups at day two (Table2). This finding confirmed the Vinoles et al. (2002) who expressed that the increased ovulation rate in ewes with high body condition was associated with increased FSH and decreased oestradiol concentrations during the follicular phase. Likewise, Garcia et al. (2002) showed that body size has an important participation in the onset of puberty and hormonal plasmatic levels were related to weight variation. Several studies have shown high correlation between FSH level and ovulation rate in ewes (Kosior, 2003; Korzecka and Bobwiec, 2003). Positive relationship have been shown between BCS and plasma leptin and FSH concentrations in Iranian fat tail ewes at mating time ( Towhidi et al., 2007).

They found also significant effect of FSH concentrations on ovulation rate in Chal ewes (Towhidi et al., 2003) and reported that FSH concentrations were significantly different after maintaining on restricted diet. They recommended flushing of ewes with low BCS before mating. The nutritional state is closely regulated by neuroendocrine and hormonal cues and energy restriction produces harmful consequences in BCS. The relationship between feeding and FSH production is directly pertinent to the above issues.

The effects of body condition score on the white blood cell and different cell counts, neutrophils and lymphocytes of ewes and their lambs are shown in Table 5. The body condition score did not significantly affect the white blood cell, different cell counts, neutrophils and lymphocytes counts. In addition, the mean white blood cell, differential cell counts, neutrophils and lymphocyte of the treated ewes did not differ significantly $(\mathrm{P}>0.05)$ after lambing. Similarly, BCS did not affect the hemato-

Table 5: Leukocyte counts in ewes at lambing, lambs at birth day and 7 days of age

Preglednica 5: Število levkocitov pri ovcah ob jagnitvi, masa jagnet ob rojstvu in na sedmi dan po rojstvu

\begin{tabular}{llcccc}
\hline & Item & BCS 2 & BCS2.5 & BSC 3 & BSC $\geq 3.5$ \\
\hline Ewes at lambing & WBC & $9966 \pm 676$ & $10098 \pm 541$ & $10100 \pm 417$ & $10000 \pm 640$ \\
& Neutrophils (\%) & $32.66 \pm 4.1$ & $31.83 \pm 2.06$ & $30.5 \pm 3.3$ & $31.60 \pm 4.4$ \\
& Lymphocyte (\%) & $66.5 \pm 1.6$ & $67.33 \pm 2$ & $68.5 \pm 2.4$ & $66 \pm 1.8$ \\
\hline Lambs at birth & WBC & $5060 \pm 437$ & $5300 \pm 206$ & $5500 \pm 394$ & $5280 \pm 340$ \\
& Neutrophils (\%) & $58.25 \pm 3.7$ & $54.75 \pm 4.8$ & $56.8 \pm 2.3$ & $58.2 \pm 3.9$ \\
& Lymphocyte (\%) & $40.25 \pm 3.2$ & $44 \pm 4.1$ & $44.2 \pm 3$ & $41.23 \pm 3.6$ \\
\hline Lambs at 7 days & WBC & $7945 \pm 443$ & $8000 \pm 533$ & $8030 \pm 308$ & $7980 \pm 323$ \\
& Neutrophils (\%) & $30 \pm 2.7$ & $29.25 \pm 1.8$ & $31.4 \pm 2$ & $30 \pm 3.7$ \\
& Lymphocyte (\%) & $68.75 \pm 3.8$ & $69.25 \pm 2$ & $68.2 \pm 2.25$ & $67.66 \pm 4.1$ \\
\hline
\end{tabular}

$(\mu \pm$ SE) Mean \pm standard error 
Table 6: Mean colostrum productions of ewes $(\mathrm{ml})$

Preglednica 6: Povprečna proizvodnja kolostruma pri ovcah $(\mathrm{ml})$

\begin{tabular}{lllll}
\hline Time & BCS 2 & BCS 2.5 & BSC 3 & BSC $\geq 3.5$ \\
\hline 1 hour postpartum & $502.65 \pm 7.21$ & $503.77 \pm 7.02$ & $508.22 \pm 6.17$ & $500 \pm 6.38$ \\
10 hours postpartum & $589.77 \pm 7.28^{\mathrm{b}}$ & $600.11 \pm 6.98^{\mathrm{b}}$ & $649 \pm 6.73^{\mathrm{a}}$ & $598 \pm 5.45^{\mathrm{b}}$ \\
18 hours postpartum & $525.65 \pm 7.41^{\mathrm{b}}$ & $530 \pm 4.45^{\mathrm{b}}$ & $603 \pm 3.72^{\mathrm{a}}$ & $536 \pm 4.33^{\mathrm{b}}$ \\
\hline
\end{tabular}

$(\mu \pm S E)$ Mean \pm standard error; Means with different superscripts in the same row differ at $\mathrm{P}<0.05$

logical indicators of lambs at birth and 7 days of age ( $\mathrm{Ta}-$ ble 5).

The mean colostrum production is shown in Table 6 . The mean colostrum production at one hour postpartum did not differ between ewes but the colostrum production at $10 \& 18$ hours postpartum increased in ewes of $\mathrm{BCS}=3(\mathrm{P}<0.05)$. Cabiddu et al. (1999) expressed that from day 120 of lactation there was a tendency towards a higher average milk yield in the herd with the highest BCS as shown by Branca and Casu (1989) and by Atti et al. (1995) in sheep. The slight negative correlation between mean BCS and the mean milk yield is in keeping with the finding of Morand-Fehr et al. (1989), this correlation is indeed much influenced by the inverse relationship during lactation between yield and BCS.

However, Cabiddu et al. (1999) expressed that at the beginning of lactation, milk yield and BCS were not correlated. Body condition score changed throughout the lactation, responding to changes in the energy balance (Coffey et al., 2003). As milk yield peaks and demand for energy exceeds intake of energy, the cow mobilizes her lipid reserves and gets thinner, all by compromising her body condition.

This process is related to the daily milk yield curve, which is almost exactly opposite to the energy balance and BCS curves (Coffey et al., 2002, 2003). Branca and Casu (1989) showed that the animals experience nutritional imbalances that can result in a marked decrease in milk yield, low milk fat and protein content and abrupt changes of body condition score. Wildman et al. (2010) reported that dairy cows of greatest efficiency of milk production showed no significant increase in body condition during lactation, had fewer days open, but had lower persistency of lactation.

The body condition scoring system is the means of accurately determining body condition of dairy cows, independent of body weight and frame size. Banos et al. (2004) expressed that a constant body condition score is associated with the ability of cow to produce milk while maintaining its energy balance. Studies relating BCS to milk production have provided inconsistent results with some (Pedron et al., 1993; Ruegg and Milton, 1995; Domecq et al., 1997) reporting no significant ef- fect of BCS at calving on subsequent milk production while others reported the contrary (Waltner et al., 1993; Markusfeld et al., 1997; Roche et al., 2007). Garnsworthy and Jones (1987) speculated that the quality of diet post-calving may influence the association between BCS at calving and milk production. Nonetheless, the impact of greater BCS loss on higher milk production is more consistent across studies (Roche et al., 2007) with high milk production associated with greater BCS loss in early lactation. The positive effect of BCS at calving on overall milk production is at odds with some previous studies (Domecq et al., 1997).

\section{CONCLUSION}

It is concluded that BCS had a significant effect on kilogram lambs born per ewes, birth weight of lambs and FSH concentration of ewes $(\mathrm{P}<0.05)$ and the score of 3 at mating time could optimize profitability of Sanjabi ewes. Ewes with BCS 3 had normal estrous while ewes with lower BCS had shorter estrous period. In whole ewes with body condition score (BCS) of 3 had a better performance.

\section{ACKNOWLEDGEMENTS}

Authors are grateful to the Raz University of Kermanshah Branch and Islamic Azad University of Saveh Branch for scientific support to carry out this work.

\section{REFERENCES}

Atti N., Nefzaoui A., Boquier F. 1995. Effect of lambing body condition score on performance, energetic balance and plasma metabolites levels in Barbary ewes. In: Options Mediterraneennes. Purroy A. (ed.). A-27: 25-33

Bonos G., Brotherstone S., Coffy M.P. 2004. Evaluation of body condition score measured throughout lactation as an indicator of fertility in dairy cattle. J. Dairy Sci: 2669-2676

Branca A., Casu S. 1989. Body condition score annual evolution and its relationship with body reserves in Sarda goat. 
In: Symposium "Philoetios", 23-25 Sept. 1987, Fonte-Boa (Portugal) Levaluation des ovins et des caprins mediterraneens. Flamant J.C., Morand-Fehr P. (eds.). Rapport EUR 11893, OPOCE, Luxembourg: 221-236

Butler W.R. 2001. Nutritional effects on resumption of ovarian cyclicity and conception rate in postpartum dairy cows. BSAS Occas. Publ. 26: 33-145

Cabiddu A., Branca A., Decandia M., Pes A., Santucci P.M., Masoero F., Calamari L. 1999. Relationship between body condition score, metabolic profile, milk yield and milk composition in goats browsing a Mediterranean shrubland. Livestock Production Science: 267-273

Caldeira R.M, Belo A.T., Santos C.C., Vazques M.I., Portugal A.V. 2007. The effect of body condition score on blood metabolites and hormonal profiles in ewes. Small Ruminant Research: 233-241

Coffey M.P., Simm G., Brotherstone S. 2002. Energy balance profiles for the first three lactations of dairy cows estimated using random regression. J. Dairy Sci. 85: 2669-2678

Coffey M.P., Simm G., Hill W.G., Brotherstone S. 2003. Genetic evaluations of dairy bulls for daughter energy balance profiles using linear type scores and body condition score analyzed using random regressions. J. Dairy Sci., 86: 2205-2212

Dacie J.V., Lewis S.M. 1984. Practical haematology. Churchill Livingston Edinburg: 22-49

Dechow C.D., Rogers G.W., Clay J.S. 2001. Heritabilities and correlations among body condition scores, production traits, and reproductive performance. J. Dairy Sci., 84: 266-275

Domecq J.J., Skidmore A.L., Lloyd J.W., Kaneene J.B. 1997. Relationship between body condition scores and milk yield in a large dairy herd of high yielding Holstein cows. Journal of Dairy Science, 80: 101-112

Dubeuf J.P., Boyazoglu J. 2009. An international panorama of goat selection and breeds. Livest. Sci., 120: 225-231

Findlay J.K., Cumming I.A. 1976. FSH in the ewe: effects of season, live weight and plane of nutrition on plasma FSH and ovulation rate. Biology of Reproduction, 15: 335-342

Gamez Vazquez H.G., Rosales Nieto R., Banuelos Valenzuela J., Urrutia Morales M., Meza Herrea C.A. 2008. Body condition score positively influence plasma leptin concentration in Criollo goats. Journal of Animal Vet Advances, 7: $1237-1240$

Garcia M.R., Amstlden M., Williams S.W., Stanko R.L., Morrison C.D., Keisler D.H., Niezielski S.E., Williams G.L. 2002. Serum leptin and its adipose gene expression during pubertal development, the estrous cycle and different seasons in cattle. Journal Animal Sci, 80, 8: 2158-2167.

Garnsworthy P.C., Jones G.P. 1987. The influence of body condition at calving and dietary protein supply on voluntary food intake and performance in dairy cows. Animal Production, 44, 347-353

Gillund P., Reksen O., Gro"hn Y.T., Karlberg K. 2001. Body condition related to ketosis and reproductive performance in Norwegian dairy cows. J. Dairy Sci., 84: 1390-1396

Gunn R.G., Doney J.M. 1975. FSH in the ewe: effects of season, live weight and plane of nutrition on plasma FSH and ovulation rate. J. Agric. Sci., Camb., 85: 465-470
Hines K.K., Hodge S.L., Kreider J.L., Potter G.D., Harms P.G. 1987. Relationship between body condition and levels of serum luteinizing hormone in postpartum mares. Theriogenology, 28: 815-825

Schillo K.K. 1992. Effects of dietary energy on control of luteinizing hormone secretion in cattle and sheep. J. Anim. Sci., 70: $1271-1282$

Jain N.C. 1986. Schism 's veterinary hematology. Lea and Febiger, Philadelphia: 66-67

Jalilian M.T., Moeini M.M. 2012. The effect of body condition score of Morghoz goats on reproductive parameters were studied. $5^{\text {th }}$ congress of animal science association, Isfehan University, 1-3 Sep. (Abstract book)

Ketema T.K. 2007. Production and marketing system of sheep and goat in Alaba, southeastern Ethiopia. M.Sc. Thesis. Hawassa University. Ethiopia

Kida K., 2002. The metabolic profile test: its practicability in assessing feeding management and periparturient diseases in high yielding commercial dairy herds. J. Vet. Med. Sci., 64: 557-563

Kosior Korzecka U., Bobowiec R. 2003. Changes in the level of endogenous leptin, $17 \beta$-oestradiol, FSH and metabolites during Lupin-induced increase in ovulation rate in ewes. Journal Vet Med Sci, 50: 343-349

Lee A.J., Twardock A.R., Bubar R.H., Hall J.E., Davis C.L. 1978. Blood metabolic profiles: their use and relation to nutritional status of dairy cows. J. Dairy Sci., 61: 1652-1670

Loeffler S.H., de Vries M.J., Schukken Y.H., de Zeeuw A.C., Dijkhuizen A.A., de Graaf F.M., Brand A. 1999. Use of AI technician scores for body condition, uterine tone and uterine discharge in a model with disease and milk production parameters to predict pregnancy risk at first AI in Holstein dairy cows. Theriogenology, 51: 1267-1284

Markusfeld O., Gallon N., Ezra E. 1997. Body condition score, health, yield and fertility in dairy cows. The Veterinary Record, 141: 67-72

Morand-Fehr P., Branca A., Santucci P.M., Napoleone M. 1989. Methods for estimating body conditions of adult goats. This study was part funded by European Union. In: L'evaluation des INTERREG 1 Funds. ovins et des caprins mediterraneens. Symposium "Philoetios", Fonte-Boa (Portugal), 23-25 Sept. 1987. Flamant J.C., Morand-Fehr P. (eds.). Luxembourg, Rapport EUR 11893, OPOCE: 109-128

National Research Council. 1985. Nutrient Requirements of Sheep. 6th ed. Washington, DC., Natl. Acad. Press

Payne J.M., Payne S. 1987. The Metabolic Profile Test. Oxford University Press, UK.

Pedron O., Cheli F., Senatore E., Baroli D., Rizzi R. 1993. Effect of body condition score at calving on performance, some blood parameters, and milk fatty acid composition in dairy cows. Journal of Dairy Science, 76: 2528-2535

Rhind S.M., McNeilly A.S. 1986. Follicle populations, ovulation rates and plasma profiles of LH, FSH and prolactin in Scottish Blackface ewes in high and low levels of body condition. Animal Reproduction Science, 10: 105-115

Rhind S.M., Leslie L.D., Gunn R.G. Doney J.M. 1985. Plasma $\mathrm{FSH}, \mathrm{LH}$, prolactin and progesterone profiles of Cheviot ewes with different levels of intake before and after mating, 
and associated effects on reproductive performance. Animal Reproduction Science, 8: 301-313

Rhind S.M., McMillen S., McKelvey W.A., Rodriguez-Herrejon F.F. McNeilly A.S. 1989. Effect of the body condition of ewes on the secretion of LH and FSH and the pituitary response to gonadotrophin-releasing hormone. Journal of Endocrinology, 120: 497-502

Roche J.R., Lee J.M., Macdonald K.A., Berry D.P. 2007. Relationships between body condition score, body weight and milk production variables in pasture-based dairy cows. Journal of Dairy Science, doi:10.3168/jds.2006-740

Rowlands G.J. 1980. A review of variations in the concentration of metabolites in the blood of beef and dairy cattle associated with physiology, nutrition and disease, with particular referenceto the interpretation of metabolic profiles. World Rev. Nutr. Diet, 35: 172-235

Ruegg P.L., Milton R.L. 1995. Body condition scores of Holstein cows on Prince Edward Island; relationships with yield, reproductive performance, and disease. Journal of Dairy Science, 78: 552-564

Santos J.E.P., DePeters E.J., Jardon P.W., Huber J.T. 2001. Effect of prepartum dietary protein level on performance of primigravid and multiparous holstein dairy cows. J. Dairy Sci., 84: 213-224

Santucci P.M., Maestrini O. 1985. Body condition of dairy goats.

SAS Institute. 2003. SAS Users Guide. Version 9.1 reviews. SAS Institute Inc, Cary

Smith A.J., Stewart R.D. 1990. Effects of nutrition on the ovulation rate of ewes. In: Reproductive Physiology of Merino Sheep: Concepts and Consequences. Oldham C.M., Martin G.B., Purvis I.W. (eds.). Canberra: School of Agriculture (Animal Science), The University of Western Australia: 85-101

Snijders S.E.M., Dillon P., O'Callaghan D., Boland M.P. 2000. Effect of genetic merit, milk yield, body condition and lactation number on in vitro oocyte development in dairy cows. Theriogenology, 53: 981-989

Stevenson J.S., Kobayashi Y., Thompson F.N. 1999. Reproductive performance of dairy cows in various programmed breeding systems including OVSYNCH and combinations of gonadotropin-releasing hormone and prostaglandin $\mathrm{F}$ 2a. J. Dairy Sci., 82: 506-515

Sun Z.H., Tan Z.L., Yao J.H., Tang Z.R., Shan J.G., Hu J.P., Tang S.X., Jiang Y.M. 2007. Effects of intra-duodenal infusion of limiting amino acids on plasma insulin-like growth factor I, growth hormone, insulin and liver insulin-like growth factor I mRNA in growing goat fed a maize stover-based diet. Asian-Aust. J. Anim. Sci., 20: 733-741

Thomas P.C., Chamberlain D.G., Martin P.A., Robertson S. 1987. Dietary energy intake and milk yield and composition in dairy cows. In: Proceedings of the 10th International
Symposium on Energy Metabolism. Moe P.W., Tyrell H.F., Reynolds P.W. (eds.). Airlie, EAAP, 17-20

Thompson M.I., Cheeke P.R. 2005. Feeding and Nutrition of Small Ruminants": sheep, Goats and Lamas. Applied Animal Nutrition. 3rd Edition, by Peter R., Cheeke Pearson Prentic Hall, New Jersy, USA.

Thornton P.K., van de Steeg J., Notenbaert A., Herrero M. 2009. The impact of climate change on livestock and livestock systems in developing countries: A review of what we know and what we need to know. Agric.sys., 101: 113-127

Towhidi A. 2003. The effect of energy and leptin on reproductive metabolic hormones secretion and the level of ovulation in Shall ewes. Ph.D. Thesis, Tarbiat Modares University, IRAN

Towhidi A., Masoumi R., Moeini M.M., Solki H., Morovaj H. 2007. The relationship between plasma of Leptin and FSH concentrations with ovulation rate in Iranian native sheep. Pakistan biological science, 10: 363-367

Treacher R.J., Reid I.M., Roberts C.J. 1986. Effect of body condition at calving on the health and performance of dairy cows. Anim. Prod., 43: 1-6

Van de Ligt C.P.A., Lindemann M.D., Cromwell G.L. 2002. Assessment of chromium tripicolinate supplementation and dietary protein level on growth, carcass, and blood criteria in growing pigs. J. Anim. Sci., 80: 2412-2419

Vargas C.A, Olson T.A., Chase C.C., Hammond JR.A.C., Elzo M.A. 1999. Influence of frame size and body condition score on performance of Brahman cattle. J. Anim. Sci., 3140-3149

Vinoles C., Forsberg M., Banchero G., Rubianes E. 2002. Ovarian follicular dynamics and endocrine profiles in Polwarth ewes with high and low body condition. Animal Science, 74: 539-545

Vinoles C., Forsberg M., Martin G.B., Cajarville C., Repetto J., Meikle A. 2005. Short-term nutritional supplementation of ewes in low body condition affects follicle development due to an increase in glucose and metabolic hormones. Reproduction, 129: 299-309

Waltner S.S., McNamara J.P., Hillers J.K. 1993. Relationships of body condition score to production variables in high producing Holstein dairy cows. Journal of Dairy Science, 76: 3410-3419

Xu Z.Z., McDonald M.F., McCutcheon S.N. 1989. The effects of nutritionally induced live weight differences on follicular development, ovulation rate, oestrus activity and plasma follicle stimulating hormone levels in the ewe. Animal Reproduction Science, 19: 67-78

Zhang S., Blache D., Blackberry M.A., Martin G.M. 2005. Body reserve affects the reproductive endocrine responses to an acute change in nutrition in mature male sheep. Animal Reprod Sci, 88, 3-4: 257-269 